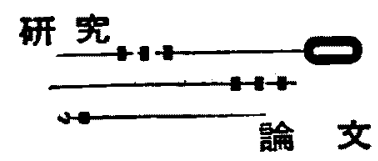

\title{
747. ${ }^{235} \mathrm{U},{ }^{239} \mathrm{Pu}$ および ${ }^{233} \mathrm{U}$ の高速中性子核分裂による 核分裂生成物からの $\beta$ 線崩壊熱の測定
}

\author{
秋山”雅胤*,古田 ${ }^{\vee}$ 一雄*, \\ 并田 俊雄**,坂田 薰*,
}

（1982年 2 月 1 日受 理）

(1982年 6 月 8 日 再受理)

Measurements of Beta-Ray Decay Heat of Fission Products

for Fast Neutron Fissions of ${ }^{235} \mathrm{U},{ }^{239} \mathrm{Pu}$ and ${ }^{233} \mathrm{U}$

By Masatsugu AKIYAMA, Kazuo FURUTA, Toshio IDA, Kaoru SAKATA and Shigehiro AN

\begin{abstract}
Beta decay heat released from fission products (FPs) has been measured for fast-neutron fissions of ${ }^{235} \mathrm{U},{ }^{230} \mathrm{Pu}$ and ${ }^{233} \mathrm{U}$ using the radiation spectrometry method. The sample irradiations were for 10,60 and $300 \mathrm{~s}$ ( 10 and $100 \mathrm{~s}$ for ${ }^{233} \mathrm{U}$ ) in the fast neutron source reactor YAYOI of the University of Tokyo. Spectral data for $\beta$-ray were obtained at post-irradiation time intervals ranging $11 \sim 26,000 \mathrm{~s}$ using a plastic scintillation detector combined with a transmission type proportional counter to eliminate $\gamma$-ray effects. The data were processed to the form of $\beta$-energy release rates per fission for each set of time-interval parameters. The standard representation of the decay heat following fission pulse (in cooling times ranging 19 24,000 s) was provided from the $\beta$-energy release rates. The experimental uncertainties $(1 \sigma)$ of the decay heat data were within $5 \%$.

The present results are compared with three summation calculations using JNDC, TASAKA and ENDF/B-11 FP decay data libraries, and with other experimental results. As the results of these comparisons, it appears that the values calculated using INDC FP decay data library agree very well with the measured values.
\end{abstract}

KEYWORDS: uranium 235, plutonium 239, uranium 233, decay heat, fission products, fast neutron fission, energy release rate, beta ray, summation calculation, comparative evaluations, energy spectra

\section{I . 腥 言}

高速中性子核分裂化上る核分裂生成物(FP)からの崩 㙘熱の測定例は少なく、これまでに次の 5 ダループの 実験があるにすぎない。放射線計测法を用いた実験と して, (1)Fisher \& Engle II に拈いてバス照射した ${ }^{238} \mathrm{Th},{ }^{238} \mathrm{U},{ }^{285} \mathrm{U},{ }^{238} \mathrm{U}$ 扰よ び ${ }^{230} \mathrm{Pu}$ 試料からの $\gamma$ 線崩壊熱を冷却時間 $0.2 \sim 45 \mathrm{~s}$ の 篹团で測定した実験, (2Bunney \& Sam ${ }^{(2)}$ による電子 楾型加速器を用いた $(\gamma, n)$ 反応中性子源で照射した
${ }^{235} \mathrm{U}$ と ${ }^{238} \mathrm{U}$ 試料から放出される クトルを冷却時間 $15 \mathrm{~min} 〜 78 \mathrm{~h}$ の範团で測定した突 験，(3)Murphy ら (3)によるぜ口出力高速奶Zebraを用い $て 10^{3} \mathrm{~s}$ 照射した ${ }^{235} \mathrm{U}$ 括よび ${ }^{239} \mathrm{Pu}$ 試料からの $\beta$ 線崩 壊熱を冷却時間 $44 \mathrm{~s}\left({ }^{235} \mathrm{U}\right.$ について)あるいは $14 \mathrm{~s}$

* 東京大学工学部附属原子力工学研究施設 (Nucl. Eng. Res. Lab., Fac. of Eng., Univ. of Tokyo)

** 東京大学工学部原子力工学科 (Dept. of Nucl. Eng., Fac. of Eng., Univ. of Tokyo)

† 現在,三菱原子力工業㑣 (Mitsubishi At. Power Ind., Inc.) 
( ${ }^{38} \mathrm{Pu}$ について) $3 \times 10^{7} \mathrm{~s}$ の範围で測定した実験が ある。カロリーメータ法を用いた実験としては, (4) Johnston'心よる Dounreay Fast Reactorを用いて 82 および $125 \mathrm{~d}$ の間で断続的に照射した ${ }^{280} \mathrm{Pu}$ 試料から の崩埧熱を冷却時間 40〜150d Kわたって測定した実

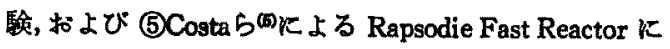
お゙いて 3 年間照射した ${ }^{225} \mathrm{U}$ と ${ }^{390} \mathrm{Pu}$ の混合然料ピンか らの崩壊熱を冷却時間21 86d の間で測定した実験が ある。しかしこれらの央験データのらち原子炉の安 全性上重要な命却時間䇶围で測定精度がよく，しかる 最近の総和計算値との一致がよいものは Murphy らの 実験值のみである。このように高速中性子核分裂によ

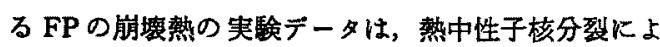
ろFPからの崩壤熱の実験データと比へて質,量ともに 不充分な状態である。

高速中性子核分裂による FP からの崩䏅熱を原子帄 の安全性上重要な冾却時間範团に就いて, 高速炬の安 全性上要求される精度の内で実験的に得ること，その 結果を基に総和計算値の評価を行うことを目的として 実験を行なった。実験は東京大学高速中性子源灯「弥 生」で照射された ${ }^{285} \mathrm{U},{ }^{230} \mathrm{Pu},{ }^{233} \mathrm{U}$ 試料からの $\beta$ 線 ネルギースベクトルを冷却時間の関数として湘定し， それから $\beta$ 線崩罗热を求める万法，いわゆる放射線計 測法を用いて行なった。これらの実験值と現在国内で よく使用されている3 種のFP崩壤データライブラリ 一を用いた総和計算值お゙び Murphy らの実験値との 比較検討を行なった。 $\gamma$ 線崩壊熱の測定結果について はすでに報告している(か。

\section{II. 実 験}

${ }^{235} \mathrm{U},{ }^{239} \mathrm{Pu},{ }^{238} \mathrm{U}$ の高速中性子核分列による FP から $の \beta$ 線崩燷熱を放射線計測法を用いて测定した。試料 は「弥生」のB運転位珇グレージング孔( (8X)内で照射さ れた。照射啳の試料から放出される $\beta$ 線のエネルギー スペクトルは $\beta-\gamma$ 弁別用透過型比例計数管と, 井戸型 ブラスチックシンチレーション険出器とを組み合わせ た $\beta$ 線スペクトロメータを用いて剆定された。 $\beta$ 線崩 壤熱は測定されたバルス波高分布を単位測定時問，1 核分裂当りに規格化したェネルギースペクトルに変換 した後にエネルギーについて積分することにより求め られた。核分裂数の決定は $\mathrm{Ge}$ 検出器を用いて特定の FP 核種から放出される $\gamma$ 線の強度を测定することに より行われた。

実験で用いた試料，照射および測定の手順，核分裂数 の測定方法等は $\gamma$ 線崩壤熱の測定ゆの場合と同じであ る。したがって，r線崩壊熱の湘定の場合と同じとこ ろは基本的な点のみを記述し，異なる点のみを詳細化 述べる。

\section{1. 試料およひ昭射装置}

実験に用いた試料恃直径 $18 \mathrm{~mm}$, 厚さ $0.1 \mathrm{~mm}$ の $\mathrm{Ti}$

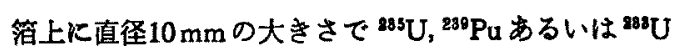
金属を約 $1.6 \mathrm{mg}$ 均一飞電着し, 電着面上㴟さ $10 \mathrm{~g} /$ m²のマイラーフィルムをかぶせ, 周囲を塩化ビニール 製リングで固定したものである。核分裂性物質やFP の飛散、漏洩を防ぐため，これらの試料の電着面代さ らに厚さ $32 \mathrm{~g} / \mathrm{m}^{2}$ のマイラーフィルムをのせて周围を

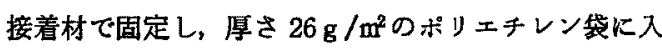
れて密封した状熊で使用した。試料はポリエチレン製 カブセルの先端に電着面を外向きにして装着され，照 射された。

試料の照射は「弥生」B運転位置グレージングれ心 に照射位置をるつ気送管照射装置を用いて行われた。

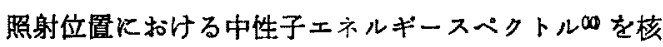
分裂エネルギースペクトルと， $1,000 \mathrm{MWe}$ の $\mathrm{Na}$ 冷却 高速增殖炉の中性子エネルギースペクトル(11) と合和 せてFig. 1 に示す。

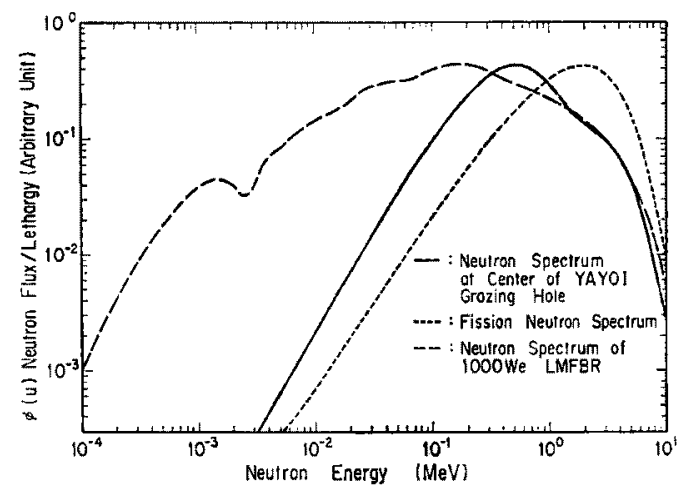

Fig. 1 Neutron energy spectrum at center of grazing hole of YAYOI reactor where samples were irradiated

試料を装着したカブセルは原子姖の定常運転状態の ときに約 $20 \mathrm{~m} / \mathrm{s}$ の速度で照射位置まで投送され，照 射終了時には同し速度で引き戻される。カブセルの反 応度は小さいので,カプセルの括入・引出しK伴ら原子 炬への外乱は小さく，照射位道での中性子束の変動は 無視できるしたがって，試料内で発生する核分裂反 応率は照射時間中一定であると仮定できる。照射時間 の制御は気送管昭射装圈の制御薜植で行なっている が,カブセルの拽入・引出しは制御装置の信号により電 
磁弁を關閉させることで行われるため，照射時間の精 度は約 $0.1 \mathrm{~s}$ である。

\section{2. $\boldsymbol{\beta}$ 線スベクトロメータとその特性}

照射試料から放出される時間依存エネルギースペク トルを大気王中で測定できる新しい $\beta$ 線スベクトロ

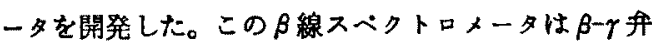
別用透過型比例計数管と井戸型ブラスチックシンチレ ーション検出器とがら構成されている。 $\beta-\gamma$ 弁别用透 過型比例計数管は 1 辺が $150 \mathrm{~mm}$ の正方形で厚さ 20 $\mathrm{mm}$ の箱型で,両面の中心に直径 $60 \mathrm{~mm}$ の透過突をむつ 形状をしている(Fig. 2)。この箱は $2 \mathrm{~mm}$ 厚の $\mathrm{Al}$ 製 で，透過空には金蒸着が施されたボリバラキシレンの 薄膜(厚さ約 $1.5 \mathrm{~g} / \mathrm{m}^{2}$ )が張られている。陽極線は0.05 $\mathrm{mm} \phi$ のングステン線で，平行等間隔に 5 本張られ ている。この比例計数管は PR ガス(Ar $90 \%+\mathrm{CH}_{4} 10$ \%)を用いたガスフロー型で，50 keV 以上の $\beta$ 線を計 湘でき，100 keV 以上の $\gamma$ 線に対する感度は無視でき るほど小さい特性をむっている。この比例計数管のパ

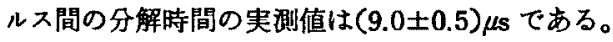

Plastic Scintillator

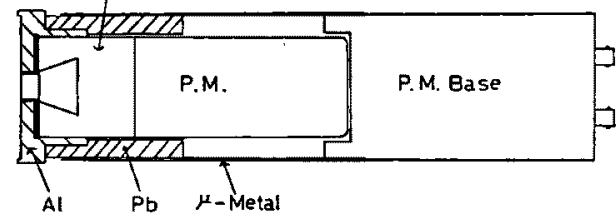

(a) Plostic scintillation detector

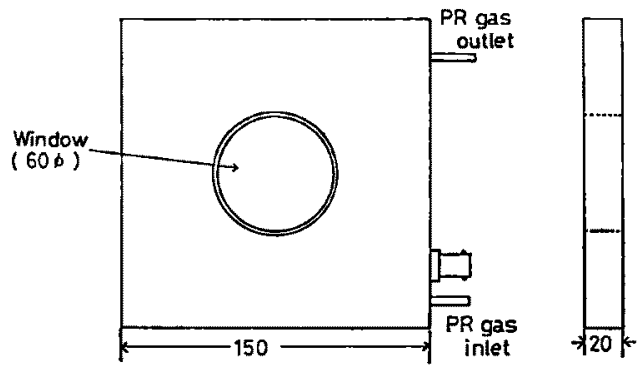

(b) Transmission type proportional counter

Fig. 2 Well-type plastic "scintillation detector and transmission type proportional counter

井戸型ブラスチックシンチレータは直径 $50.8 \mathrm{~mm}$ ， 長さ50 $\mathrm{mm}$ の円柱で，片面中心に入口径 $16 \mathrm{~mm}$ ，底面 径 $30 \mathrm{~mm}$ で深さ $20 \mathrm{~mm}$ の井户をすった形状をしてい る。井戸の反対面には光電子增倍管(EMI-9813KB)か; 取り付けられている。光電子増倍管の接着面を除く全 面には光反射膜としてVHエナメル白色塗料が $0.1 \mathrm{~mm}$ 厚で榃布されている。また，光遮蔽として $34 \mathrm{~g} / \mathrm{m}^{2}$ 厚
の黒色ポリエチレンフィルムが使用されれている。シン チレータ䫁面は直径 $15 \mathrm{~mm}$ の入射孔をるつ $\mathrm{Pb}$ で張 クされた $\mathrm{Al}$ 製遮蔽，側面は $\mathrm{Pb}$ 製遮蔽で覆われてい Ђ(Fig. 2)。

$\beta-\gamma$ 弁別用透過型比例計数管をブラスチックシンチ レーション検出器の前面に中心を合わせて密着させて 使用する。シンチレーション検出器と反対側の透過密 には直径 $15 \mathrm{~mm}$ の入射孔をるつ厚さ $9 \mathrm{~mm}$ の Pbで内 張りされた $\mathrm{Al}$ 製コリメータが取り付けられている。 照射された試料はコリメー夕前面から $3 \mathrm{~mm}$ の位直に 止まるように試料受けが設定されている。この状態て の試料とブラスチックシンチレータの井戸底面の間に

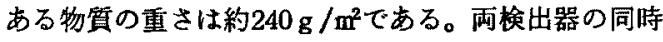
計数をとることにより， $\gamma$ 線の效果を除外して $\beta$ 線の みのェネルギースベクトルが測定できる。

$\beta$ 線スペクトロメータの応答関数は，東京大学原子 核研究所の空芯 $\beta$ 線スペクトロメータ(12) (18)から引き出 した単色電子線，標造内部転換電子線源就よび標準 $\beta$ 線源を用いて測定された。空芯 $\beta$ 線スベクトロメータ は用いる $\beta$ 線源の $\beta$ 楾最大土ネルギー以下の任意のエ ネルギーの電子線を非常によいエネルギー分解能で得 ることができる。 $\beta$ 線源として ${ }^{144} \mathrm{Ce}^{-14} \operatorname{Pr}$ 線源を用い て $0.3 \sim 2.7 \mathrm{MeV}$ の間の 15 エネルギー点での単色電子 楾を空芯州線スペクトロメータから外部に引き出し， その単色電子線に対する $\beta$ 線スペクトロメータの応答 関数を湘定した。この湘定結果から,ピーク位置, ピー ク成分の半值幅およびピーク成分に対する後方散乱に よる低ェネルギー成分の割合の入射電子ェネルギーと の関俰が求められた。

ピーク位置と入射電子エネルギーとの関係は $1 \mathrm{MeV}$ 以上では直線性が成り立ち，1 MeV以下では線源とシ ンチレータとの間の物質層に上る吸収のため直線性か らずれてくる。ピーク成分の形はガウス関数でよくフ ィットされ, その半值幅 $w$ は入射電子ェネルギー $E_{\text {。 }}$ を $\mathrm{MeV}$ 単位で表わすと。

$$
w=\sqrt{2.127 \times 10^{-3} \cdot E_{e}^{2}+1.972 \times 10^{-2} \cdot E_{q}}
$$

の関係式で表わされる (14)。一方， $\beta$ 線スペクトロメ一 夕の検出效率の絶対值は ${ }^{207} \mathrm{Bi},{ }^{177} \mathrm{Cs},{ }^{113} \mathrm{Sn}$ の標準内部 転換電子線源と ${ }^{204} \mathrm{TI}{ }^{80} \mathrm{Sr},{ }^{00} \mathrm{Sr}-{ }^{00} \mathrm{Y},{ }^{140} \mathrm{Ce}-{ }^{144} \mathrm{Pr}$ の標準 $\beta$ 線源を用いて決められ，その值は入射電子エネルギ 一によらず一定で, $4.42 \times 10^{-3}$ (counts/ $\beta$ )である。

これらの測定結果を用いて， $\beta$ 線エネルギー0.2〜 $8 \mathrm{MeV}$ の間て100群，ハルス波高 340 群の応答関数を 作成した。応答関数のエネルギー群構造をTable 1 に 
示す。をた応答関の 1 例をFig.3に示 す。 ${ }^{00} \mathrm{Sr}-{ }^{90} \mathrm{Y}$ 標準 $\beta$ 線源かららの $\beta$ 線の测 定されたパルス波高分有をこの応答関数 を用いてエネルギースペクトルに変換し た結果と計算された $\beta$ 線エネルギースペ クトルとの比較図をFig.4k示す。実験 值と計算值とは $1 \mathrm{MeV}$ 以上の面積で覞 格化してある。低エネルギー側で若干の 食い違いはあるが、全体として雨者はよ く一致している。

\section{Ti箔による $\beta$ 線の後方}

\section{散乱効果の補正}

用いた試料は $0.1 \mathrm{~mm}$ 厚の Ti 簿の上に 䄪 $1.6 \mathrm{mg}$ の核分裂性物質が電着されて いる。電着量は非常に少ないので自己吸 収の效果は無視でさるが、Ti 䇴による 線の後方散乱の効果は無視することがて さないしたがって, ${ }^{80} \mathrm{Sr},{ }^{80} \mathrm{Sr}-{ }^{80} \mathrm{Y},{ }^{144} \mathrm{Ce}-$ ${ }^{144} \mathrm{Pr} の 3$ 種の標準 $\beta$ 線源からの $\beta$ 線のバ ルス波高分布を線源の䝵面に $0.1 \mathrm{~mm}$ 厚 Ti 䇴を圈いた場合と固かない場合とで 测定した。ハルス波高分布をエネルギー スペクトルK変換した後，Ti 箔を固い た場合と置かない場合とのスベクトルの 比をとることにより，後方散乱効果の補 正係数を各エネルギー群ごとに次式のよ らに求めた。

$$
\begin{aligned}
g_{i}= & \frac{N_{i}(\mathrm{Ti} \text { 簿なしのスペクトルの } i \text { 群の值) }}{N_{i}(\mathrm{Ti} \text { 䇴むりのスベクトルの } i \text { 群の值) }} \\
& i=1 \sim 100
\end{aligned}
$$

3 種の $\beta$ 線源を用いて得た測定結果の平均值として補 正係数を得た。この結果をFig. 5 に示す。四中で，。 印は実験值，実線は実験値をフィットして得た補正俰

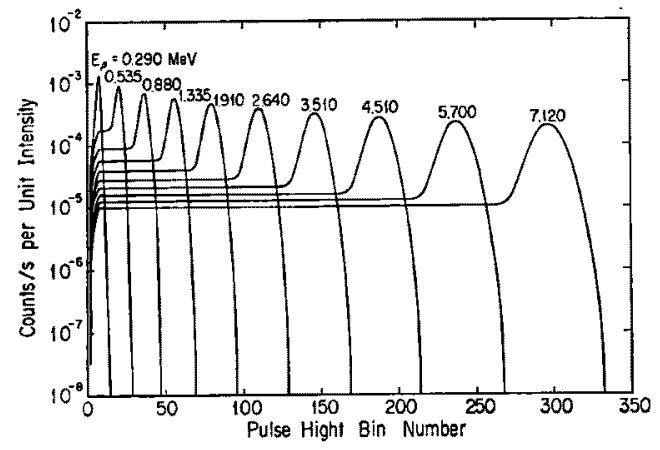

Fig. 3 Examples of responses of $\beta$-ray spectrometer to monoenergetic $\beta$-rays
Table 1 Energy group structure of response

\begin{tabular}{|c|c|c|c|c|c|c|c|c|}
\hline $\begin{array}{l}\text { Bin } \\
\text { No. }\end{array}$ & $\begin{array}{c}\text { Mid-Bin } \\
\text { Energy } \\
\text { (MeV) }\end{array}$ & $\begin{array}{c}\text { Width } \\
\text { (MeV) }\end{array}$ & $\begin{array}{l}\text { Bin } \\
\text { No. }\end{array}$ & $\begin{array}{c}\text { Mid-Bin } \\
\text { Energy } \\
(\text { MeV) }\end{array}$ & $\begin{array}{c}\text { Width } \\
\text { (MeV) }\end{array}$ & $\begin{array}{l}\text { Bin } \\
\text { No. }\end{array}$ & $\begin{array}{c}\text { Mid-Bin } \\
\text { Energy } \\
\text { (MeV) }\end{array}$ & $\begin{array}{l}\text { Width } \\
\text { (MeV) }\end{array}$ \\
\hline 1 & 0.210 & 0.02 & 36 & 1.385 & 0.05 & 71 & 4.110 & 0.10 \\
\hline 2 & 0.230 & 0.02 & 37 & 1.435 & 0.05 & 72 & 4.210 & 0.10 \\
\hline 3 & 0.250 & 0.02 & 38 & 1.490 & 0.06 & 73 & 4.310 & 0.10 \\
\hline 4 & 0.270 & 0.02 & 39 & 1.550 & 0.06 & 74 & 4.410 & 0.10 \\
\hline 5 & 0.290 & 0.02 & 40 & 1.610 & 0.06 & 75 & 4.510 & 0.10 \\
\hline 6 & 0.310 & 0.02 & 41 & 1.670 & 0.06 & 76 & 4.620 & 0.12 \\
\hline 7 & 0.330 & 0.02 & 42 & 1.730 & 0.06 & 77 & 4.740 & 0.12 \\
\hline 8 & 0.350 & 0.02 & 43 & 1.790 & 0.06 & 78 & 4.860 & 0.12 \\
\hline 9 & 0.370 & 0.02 & 44 & 1.850 & 0.06 & 79 & 4.980 & 0.12 \\
\hline 10 & 0.390 & 0.02 & 45 & 1.910 & 0.06 & 80 & 5.100 & 0.12 \\
\hline 11 & 0.415 & 0.03 & 46 & 1.975 & 0.07 & 81 & 5.220 & 0.12 \\
\hline 12 & 0.445 & 0.03 & 47 & 2.045 & 0.07 & 82 & 5.340 & 0.12 \\
\hline 13 & 0.475 & 0.03 & 48 & 2.115 & 0.07 & 83 & 5.460 & 0.12 \\
\hline 14 & 0.505 & 0.03 & 49 & 2.185 & 0.07 & 84 & 5.580 & 0.12 \\
\hline 15 & 0.535 & 0.03 & 50 & 2.255 & 0.07 & 85 & 5.700 & 0.12 \\
\hline 16 & 0.565 & 0.03 & 51 & 2.325 & 0.07 & 86 & 5.830 & 0.14 \\
\hline 17 & 0.595 & 0.03 & 52 & 2.400 & 0.08 & 87 & 5.970 & 0.14 \\
\hline 18 & 0.625 & 0.03 & 53 & 2.480 & 0.08 & 88 & 6.110 & 0.14 \\
\hline 19 & 0.655 & 0.03 & 54 & 2.560 & 0.08 & 89 & 6.250 & 0.14 \\
\hline 20 & 0.685 & 0.03 & 55 & 2.640 & 0.08 & 90 & 6.390 & 0.14 \\
\hline 21 & 0.720 & 0.04 & 56 & 2.720 & 0.08 & 91 & 6.530 & 0.14 \\
\hline 22 & 0.760 & 0.04 & 57 & 2.800 & 0.08 & 92 & 6.670 & 0.14 \\
\hline 23 & 0.800 & 0.04 & 58 & 2.880 & 0.08 & 93 & 6.810 & 0.14 \\
\hline 24 & 0.840 & 0.04 & 59 & 2.965 & 0.09 & 94 & 6.960 & 0.16 \\
\hline 25 & 0.880 & 0.04 & 60 & 3.055 & 0.09 & 95 & 7.120 & 0.16 \\
\hline 26 & 0.920 & 0.04 & 61 & 3.145 & 0.09 & 96 & 7.280 & 0.16 \\
\hline 27 & 0.960 & 0.04 & 62 & 3.235 & 0.09 & 97 & 7.440 & 0.16 \\
\hline 28 & 1.000 & 0.04 & 63 & 3.325 & 0.09 & 98 & 7.600 & 0.16 \\
\hline 29 & 1.040 & 0.04 & 64 & 3.415 & 0.09 & 99 & 7.760 & 0.16 \\
\hline 30 & 1.085 & 0.05 & 65 & 3.510 & 0.10 & 100 & 7.920 & 0.16 \\
\hline 31. & 1.135 & 0.05 & 66 & 3.610 & 0.10 & & & \\
\hline 32 & 1.185 & 0.05 & 67 & 3.710 & 0.10 & & & \\
\hline 33 & 1.235 & 0.05 & 68 & 3.810 & 0.10 & & & \\
\hline 34 & 1.285 & 0.05 & 69 & 3.910 & 0.10 & & & \\
\hline 35 & 1.335 & 0.05 & 70 & 4.010 & 0.10 & & & \\
\hline
\end{tabular}
matrix of $\beta$-ray spectrometer

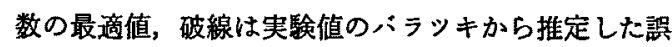
差範卌である。この圀からかかるように， $\beta$ 線エネル ギーが1.2 MeV 以上では後方散乱の效果は無視でき る。照射試料からの $\beta$ 線エネルギースペクトルにこの 補正係数を乗じるとにより，後方散乱の効果を補正 寸ることができる。

4. 冷却時間依存 $\boldsymbol{\beta}$ 楾エネルギースベクトルの測定 ${ }^{235} \mathrm{U}$ と ${ }^{238} \mathrm{Pu}$ に対しては $10 \mathrm{~s}$ 照射 2 回， $60 \mathrm{~s}$ 照射 1 回, $300 \mathrm{~s}$ 照射 1 回の計 4 回の照射を, ${ }^{283} U$ と対しては $10 \mathrm{~s}$ 照射 2 回と $100 \mathrm{~s}$ 照射 1 回の計 3 回の照射を行 ことにより，照射後 $11 〜 26,000 \mathrm{~s}$ の範国に枕ける34点 で測定を行なった。1回目の10s 照射では照射後11〜 $3,795 \mathrm{~s}$ の間で 12回, 2 回目の $10 \mathrm{~s}$ 照射では照射後 17 〜 4,395 s の間で 1 回目の測定の際に待ち時間になっ ていた部分を12回測定した。 ${ }^{235} U$ と ${ }^{288} \mathrm{Pu}$ の場合は60 s 照身後 170 7,970 s の範囲で 18回 $\left({ }^{285} \mathrm{U}\right), 170 \sim 11,970$ $\mathrm{s}$ の範团で20回 $\left.{ }^{289} \mathrm{Pu}\right)$ の測定と, $300 \mathrm{~s}$ 照射後 $1,250 \sim$ $25,850 \mathrm{~s}$ の籍国で16回の测定を行なった。 ${ }^{288} U$ の場合 


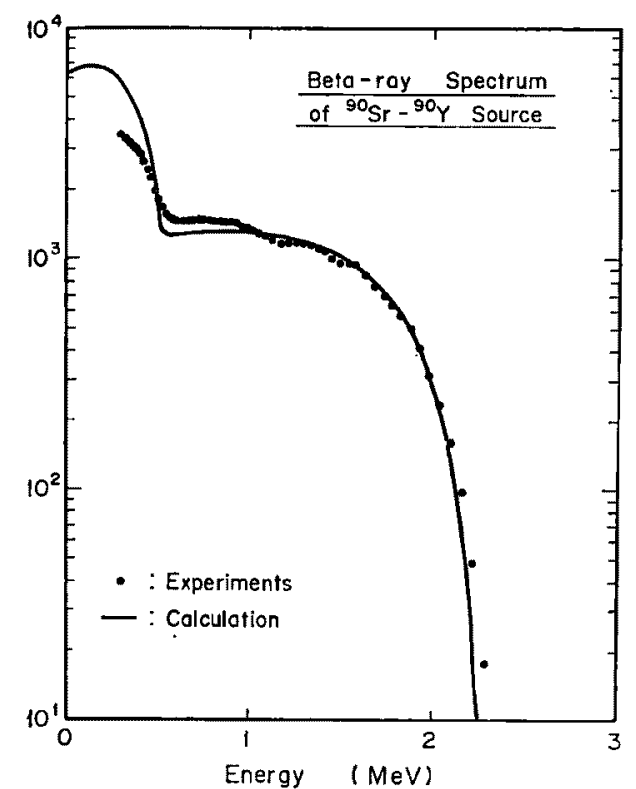

Fig. 4 Comparison between measured and calculated ${ }^{90} \mathrm{Sr}-{ }^{00} \mathrm{Y} \beta$-ray spectra

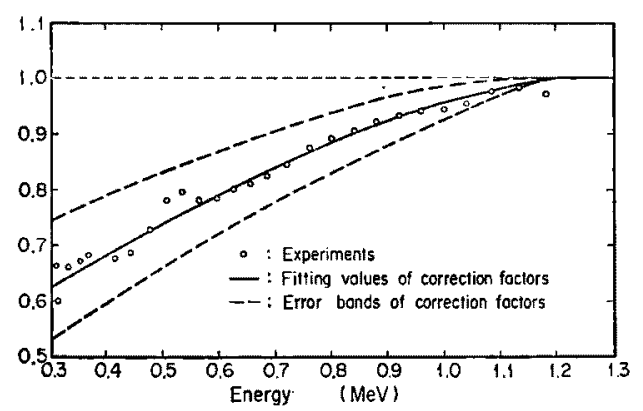

g. 5 Energy dependent correction factors for $\beta$-ray backscattering effect by $\mathrm{Ti}$ backing foil

$100 \mathrm{~s}$ 照射後 $150 \sim 25,950 \mathrm{~s}$ の範囲で24回の測定を行 った。 $60,300,100 \mathrm{~s}$ の照射後の測定の場合は各測 間に 2 sのデータ転送に必要な待ち時間が設定され いる。このような照射・湘定方式により照射後11 , $000 \mathrm{~s}$ の範用で連続的な時間依存 $\beta$ 線エネルギース クトルが湘定されだ。

照射に先立ち，各試料の固有の放射能からの $\beta$ 線エ ルギースベクトルの測定を行なった。さらに, 試料が 着されたポリエチレン製カプセル,試料の $\mathrm{Ti}$ 䈌や接 村等の中性子照射に伴ら誘導放射能からの時間侬存 $\beta$ 線エネルギースペクトルを测定するため，核分裂 物質が電着されていないことを除けばすべて同一条
件で作成された模擬試料を用いて，前述の照射・測定 方式に基ついて照射し，湘定を行なった。

これらの湘定結果を用いて，照射時間 $T_{R}$ ，待ち時間 $T_{w}$ および測定時間 $T_{\sigma}$ の各組 $\left(T_{R}, T_{w}, T_{C}\right)$ K対して， 照射試料中の FP からの $\beta$ 線による単位時間当りの真 のパス波高分布が求められた。

\section{5. 核分裂数の決定}

照射中に試料内で発生した核分裂数は照射後適当な 冷却持間をむいた後に ${ }^{97} \mathrm{Zr}$ の娘核である ${ }^{97} \mathrm{Nb} と^{87 m} \mathrm{Nb}$ から放出される とにより求められた。質量数97の崩壊系列において， ${ }^{97} \mathrm{Zr}$ より原子番号の小さい核種はその半減期が ${ }^{97} \mathrm{Zr}$ の 半減期 $\left(T_{1 / 2}=16.9 \mathrm{~h}\right)$ に比べて極端に短いので哭視し, ${ }^{97} \mathrm{Nb}$ と ${ }^{97 m} \mathrm{Nb}$ の独立收率は $3.4 \times 10^{-3} \%$ と小さいので 無視することにより, ${ }^{87} \mathrm{Zr} \rightarrow{ }^{07} \mathrm{Nb}\left({ }^{97 m} \mathrm{Nb}\right) \rightarrow{ }^{97} \mathrm{Mo}$ と崩烄 系列を単純化することができる。核分裂反应率 $n_{\boldsymbol{1}}$ は 照射時間中一定之仮定でさ， ${ }^{97} \mathrm{Zr}$ をA, ${ }^{97} \mathrm{Nb}$ あるいは ${ }^{87 m} \mathrm{Nb}$ を B と表わすと，次式で与えられる。

$$
\begin{aligned}
n_{f}= & C_{B}\left(\lambda_{B}-\lambda_{A}\right) /\left[\varepsilon_{B} \cdot b_{B} \cdot \alpha_{A}\right. \\
& \cdot\left\{\frac{\lambda_{B}}{\lambda_{A}}\left(1-e^{-\lambda_{A} \cdot T_{R}}\right)\left(1-e^{-\lambda_{A} \cdot T_{C}}\right) e^{-\lambda_{A} \cdot T_{W}}\right. \\
& \left.\left.-\frac{\lambda_{A}}{\lambda_{B}}\left(1-e^{-\lambda_{B} \cdot T_{R}}\right)\left(1-e^{-\lambda_{B} \cdot T_{C}}\right) e^{-\lambda_{B} \cdot T_{W}}\right\}\right]
\end{aligned}
$$

ここで, $T_{R}$ : 照射時間, $T_{W}$ ：待ち時間 $T_{c}$ ：測定時間

$C_{B}:$ 目的の $\gamma$ 線のピーク面積 $\varepsilon_{B}:$ 目的の $\gamma$ 線エネルギーに対する $\mathrm{Ge}$ 検出器のピーク效率

$b_{B}$ : 目的の $\gamma$ 線放出率(分岐比と内部転 換補正保数の積)

$\lambda_{A}, \lambda_{B}$ : 核種 $A, B$ の崩壦定数 $\alpha_{\Delta}$ : 核種 $A$ の照積核分裂收率

したがって，全核分裂数は $N_{f}=n_{f} \cdot T_{R}$ として与えら れ， ${ }^{97} \mathrm{Nb}$ と ${ }^{97 \mathrm{~m}} \mathrm{Nb}$ とから得られた值の平均值として 求めた。ここで，累積核分裂収率はRider \& Meekの 評価值 ${ }^{(15)}$ を，崩铰定数と $\gamma$ 線放出率は Table of Isotopes (第 7 版) ${ }^{(16)}$ の值を使用した。用いたこれらの值 をTable 2 K，得られた核分裂数をTable 3 に示す。

\section{III . 測定結果およびデータ解析}

${ }^{235} \mathrm{U},{ }^{230} \mathrm{Pu},{ }^{280} \mathrm{U}$ のそれでれの試料に対して，照射時 間 $T_{z}$, 待ち時間 $T_{W}$, 測定時間 $T_{0}$ の組 $\left(T_{B}, T_{\mathrm{W}}, T_{c}\right)$ ごとに単位時間当りのハルス波高分布が得られた。こ のパルス波高分布をエネルギースペクトルに变換し， 
Table 2 Parameters used in determination of number of fissions

(a) Decay data

\begin{tabular}{lll}
\hline \multicolumn{1}{c}{ Nuclide } & \multicolumn{1}{c}{${ }^{87 m} \mathrm{Nb}$} & \multicolumn{1}{c}{${ }^{87} \mathrm{Nb}$} \\
\hline Half-life & $60 \pm 8 \mathrm{~s}$ & $72.1 \pm 0.7 \mathrm{~m}$ \\
$\gamma$-ray energy $(\mathrm{MeV})$ & 0.743 & 0.658 \\
$\gamma$-ray branching $(\%)$ & $92.8 \pm 0.3$ & $98.2 \pm 0.1$ \\
\hline
\end{tabular}

(b) Fission yields of ${ }^{97} \mathrm{Zr}$

Nuclide ${ }^{235} \mathrm{U} \quad{ }^{239} \mathrm{Pu} \quad{ }^{238} \mathrm{U}$

Fission yield (\%) $5.947 \pm 0.042 \quad 5.273 \pm 0.053 \quad 5.457 \pm 0.055$

Table 3 Determination of number of fissions (a) ${ }^{885} \mathrm{U}$

\begin{tabular}{|c|c|c|c|c|}
\hline Sample No. & U5-11 & U5-1 & U5-13 & U5-10 \\
\hline $\begin{array}{r}\text { Irradiation } \\
\text { time (s) }\end{array}$ & 10 & 10 & 60 & 300 \\
\hline${ }^{97 m} \mathrm{Nb}$ & $\begin{array}{l}1.261 \\
\pm 0.004 t\end{array}$ & $\begin{array}{l}1.480 \\
\pm 0.051 t\end{array}$ & $\begin{array}{l}8.728 \\
\pm 0.225 t\end{array}$ & $\begin{array}{l}4.113 \\
\pm 0.099 t t\end{array}$ \\
\hline${ }^{97} \mathrm{Nb}$ & $\begin{array}{l}1.235 \\
\pm 0.040\end{array}$ & $\begin{array}{l}1.468 \\
\pm 0.047\end{array}$ & $\begin{array}{l}8.720 \\
\pm 0.219\end{array}$ & $\begin{array}{l}4.166 \\
\pm 0.099\end{array}$ \\
\hline $\begin{array}{l}\text { Average number } \\
\text { of fissions }\end{array}$ & $\begin{array}{l}1.248 \\
\pm 0.042\end{array}$ & $\begin{array}{l}1.474 \\
\pm 0.019\end{array}$ & $\begin{array}{l}8.724 \\
\pm 0.222\end{array}$ & $\begin{array}{l}4.140 \\
\pm 0.099\end{array}$ \\
\hline
\end{tabular}

(b) ${ }^{239} \mathrm{Pu}$

\begin{tabular}{|c|c|c|c|c|}
\hline Sample No. & PU-2 & PU-9 & PU-3 & PU-4 \\
\hline $\begin{array}{l}\text { Irradiation } \\
\text { time (s) }\end{array}$ & 10 & 10 & 60 & 300 \\
\hline${ }^{97 m} \mathrm{Nb}$ & $\begin{array}{l}1.660 \\
\pm 0.0633^{\dagger}\end{array}$ & $\begin{array}{l}1.745 \\
\pm 0.061 t\end{array}$ & $\begin{array}{l}1.279 \\
\pm 0.038 \mathrm{tt}\end{array}$ & $\begin{array}{l}1.386 \\
\pm 0.127 \pi t\end{array}$ \\
\hline${ }^{87} \mathrm{Nb}$ & $\begin{array}{l}1.580 \\
\pm 0.050\end{array}$ & $\begin{array}{l}1.693 \\
\pm 0.055\end{array}$ & $\begin{array}{l}1.306 \\
\pm 0.034\end{array}$ & $\begin{array}{l}1.139 \\
\pm 0.119\end{array}$ \\
\hline $\begin{array}{l}\text { Average number } \\
\text { of fissions }\end{array}$ & $\begin{array}{l}1.620 \\
\pm 0.059\end{array}$ & $\begin{array}{l}1.719 \\
\pm 0.058\end{array}$ & $\begin{array}{l}1.293 \\
\pm 0.036\end{array}$ & $\begin{array}{l}4.413 \\
\pm 0.123\end{array}$ \\
\hline
\end{tabular}

(c) ${ }^{233} \mathrm{U}$

\begin{tabular}{|c|c|c|c|}
\hline Sample No. & U3-1 & U3-2 & U3-5 \\
\hline $\begin{array}{l}\text { Irradiation } \\
\text { time }(\mathbf{s})\end{array}$ & 10 & 10 & 100 \\
\hline${ }^{97 m} \mathrm{Nb}$ & $2.846 \pm 0.112 t$ & $3.378 \pm 0.129 t$ & $3.104 \pm 0.085 t 1$ \\
\hline${ }^{97} \mathrm{Nb}$ & $3.008 \pm 0.108$ & $3.486 \pm 0.113$ & $3.040 \pm 0.071$ \\
\hline $\begin{array}{l}\text { Average nur } \\
\text { of fissions }\end{array}$ & $\begin{array}{l}\text { ber } \\
2.927 \pm 0.110\end{array}$ & $3.432 \pm 0.121$ & $3.072 \pm 0.078$ \\
\hline
\end{tabular}

単位核分裂率当りに規格化した後，エネルギーについ て稳分することにより有限時間炤射崩境熱を得た。さ らに,これらの有限時間照射崩烄熱を瞬時照射崩壊熱 の形に変換した。

\section{1. $\beta$ 線エネルギースベクトルの導出}

ベルス波高分布 $C(I)$ とエネルギースヘクトル $\phi(E)$ とは, 次式で関係づけられる。

$$
C(I)=\int R(I, E) \cdot \phi(E) d E
$$

ここで, $R(I, E)$ は第 I-2節で述べた検出器の応答関 数である。(4)式を解いてェネルギースペクトル $\phi(E)$ を求めるのに FERDORコード(17)用いた。このよう にして得られたエネルギースペクトルに（2)式で得 られた Ti 箔による後方散乱補正係数を乗しることに より，最大エネルギー $8 \mathrm{MeV}$ で100群に分割された $\beta$ 線エネルギースペクトルを得た。

$\beta-\gamma$ 㚏別用透過型比例計数管のパルス間の分解時間

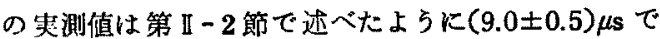
あった。一方, シンチレーション険出器の分解時間は 比例計数管のむのと此べると非常に短いので， $\beta$ 楾ス

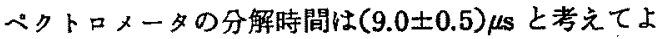
い。照射試料からの $\beta$ 線の測定の際， $\beta-\gamma$ 弁別用透過 型比例計数管の計数率は最大 $2 \times 10^{4} \mathrm{cps}$ になるので, その不感時間の補正が必要亡なる。 $\beta-\gamma$ 弁別用透過型 比例計数管とシンチレーション検出器とは同時計数测 定を行なっているので， $\beta$ - $\gamma$ 争別用透過型比例計数管 の不感時間分だけシンチレーション模出器の計数值が 隇少する。しかし湘定されたエネルギースペクトルの 形は変化しない。したがって，この不感時間に伴う補 正係数Pは $\beta-\gamma$ 弁别用透過型比例計数管の計数率の測 定時間内の平均值を $n$, 分解時間を $\tau$ とすると，

$$
P=(1-n \cdot \tau)^{-1}
$$

となる。この補正係数 $P$ を( 4 )式を解いて得たエネル ギースペクトルK，後方散乱補正係数を乗して得た前 述のエネルギースペクトルに乗じることにより，真の $\beta$ 線エネルギースベクトルが得られる。

\section{2 . 崩壊熱の導出}

\section{（1）有限特間照射崩壤熱}

照射後の試料から放出される $\beta$ 線エネルギースペク トルは冷却間ととむに变化している。しかし，第I4 節で述へた照射・測定方式に机いては，測定時間 $T$ 。 は待ち時間 $T_{w}$ に比へて十分短いので, 測定時間 $T_{0}$ 内 での $\beta$ 線エネルギースペクトルはその形は変化せず, 強度のみが時間とともに直線的に減少するすのと仮定 できる。したがって，前節で得られた各 $\left(T_{R}, T_{\mathbb{W}}, T_{0}\right)$ ことの $\beta$ 線エネルギースベクトルは， $T_{\sigma}$ 内での平均の 単位時間当りのスペクトルとみなすことができ（be$\operatorname{tas} / \mathrm{MeV} \cdot \mathrm{s})$ の次元をつ。したがって, 冾却時間 $t$ として照射终了時点から测定時間の中間点までの時間 
$\left(T_{W}+1 / 2 T_{c}\right)$ をとると，有限時間照射崩堆熟は

$$
\begin{aligned}
F\left(T_{R}, T_{w}+1 / 2 T_{c}\right)= & \frac{1}{n_{j}} \int_{0}^{z_{\operatorname{mix}}} E \cdot \phi(E) d E \\
= & \frac{1}{n_{f}} \sum_{j=I_{\min }^{I_{12}} E_{j} \cdot \phi\left(E_{j}\right) \cdot \Delta E_{j}} \\
& +\frac{1}{n_{j}} \int_{0}^{B_{\min }} E \cdot \phi(E) d E
\end{aligned}
$$

$こ こ て ， n_{s}$ : 照射中に試料内で発生した単位時間

$$
\text { 当りの核分裂数 }
$$

$E_{y}, \Delta E_{s}: j$ 群の中心エネルギーとメネハギー喓

$\phi\left(E_{f}\right): j$ 群 $\beta$ 楾束

と与えられる。(6)式の右辺第 1 項は測定されたエネ ルギースベクトルから計算される部分であり，第 2 項 は测定されたェネルギースベクトルのエネルギー下限 值以下のエネルギーをるつ $\beta$ 線からの奇与分である。 このエネルギー下限値は用いた測定系の内部ハイフス

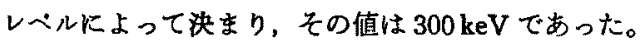
したがって, $E_{\max }=8 \mathrm{MeV}\left(I_{\max }=100\right), E_{\min }=300$ $\mathrm{keV}\left(I_{\mathrm{min}}=6\right)$ である。 $300 \mathrm{keV}$ 以下のェネルギース ベクトルは測定されたエネルギースペクトルを0エネ ルギーをで外插して求め，それを積分してェネルギー 下限值以下のエネルギーをるつ $\beta$ 線による有限時間照 射崩滾熱への寄与分を計算した。この奇与分の有限時 間照射崩㐭熱全体に対寸る割合は 1.5〜 4\%の範用であ る。(6)式で得られた有限時間照射崩堎熱を次式で与 えられるェネルギー放出量,つまり $\left(1 / T_{R}\right)$ fissions $/ \mathrm{s} の$ 割合で $T_{R}$ 時間照射した後の $T_{W}$ から $\left(T_{W}+T_{C}\right)$ 時間 内に放出されるエネルギー

$$
E\left(T_{R}, T_{W}+1 / 2 T_{C}\right)=T_{C} \cdot F\left(T_{R}, T_{W}+1 / 2 T_{C}\right) / T_{R}
$$

に变換した。 ${ }^{235} \mathrm{U},{ }^{239} \mathrm{Pu},{ }^{233} \mathrm{U}$ について( 7 )式の形にし た测定結果をそれぞれTable 4 (a)〜 (c)に示す。表には $\beta$ 線放出量と $\beta$ 線平均エネルギーる合わせて载せてあ る。ここで， $\beta$ 線放出量は次式で与えられる。

$$
\begin{aligned}
N\left(T_{R}, T_{W}+1 / 2 T_{c}\right)= & \frac{T_{\sigma}}{n_{f} \cdot T_{R}} \int_{0}^{z_{\max }} \phi(E) d E \\
= & \frac{T_{c}}{n_{f} \cdot T_{R}} \sum_{j=T_{\operatorname{mix}}}^{I_{\max }} \phi\left(E_{j}\right) \cdot \Delta E_{j} \\
& +\frac{T_{C}}{n_{f} \cdot T_{R}} \int_{0}^{z_{\min }} \phi(E) d E
\end{aligned}
$$

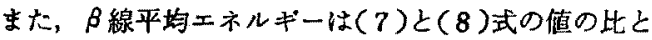

して与えられる。

(2) 瞬時照射崩塄熱

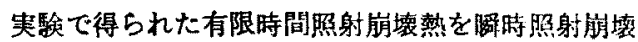

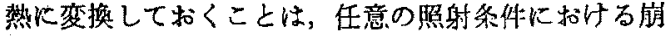
壈熱をそれから計算できること，照射条件の異なる他 の契験值あるいは計算值との比較をし易くすることな どのため有意義である。

照射時間内で核分裂反応率が一定で,生成された EP の中性子反応の効果が無視できる場合，待ち時間 $T_{w}$ が照射時間 $T_{R}$ と測定時間 $T_{c}$ の和より十分長い，つ まり $T_{w} \gg\left(T_{R}+T_{O}\right)$ が成り立つ場合は，有限時間照射 崩堙熱を照射時間で割った值は，冷却時間 $t=T_{W}+$ $1 / 2\left(T_{R}+T_{C}\right)$ での瞬時照射崩壤熱とみなすことができ る。つまり

$$
f\left(T_{W}+1 / 2\left(T_{R}+T_{C}\right)\right\}=F\left(T_{R}, T_{W}+1 / 2 T_{c}\right) / T_{R}
$$

が成り立つ。一方， $T_{\Downarrow} \leqq\left(T_{R}+T_{0}\right)$ の䈖囲においては (9)式が成り立たないので，この範囲では補正係数 $\eta$ を覓入して

$$
f\left\{T_{W}+1 / 2\left(T_{R}+T_{o}\right)\right\}=\eta \cdot F\left(T_{R}, T_{W}+1 / 2 T_{C}\right) / T_{k}
$$

により瞬時照射崩喓熱に変換した。ここで，補正保数 $\eta$ は瞬時照射条件で冾却時間 $t=T_{W}+1 / 2\left(T_{x}+T_{C}\right) \mathrm{K}$ おりる総和計算值と, 照射時間 $T_{R}$, 冷却時間 $t^{\prime}=T_{W}$ $+1 / 2 T_{c}$ における有限時間照射条件での総和語算值と の比として，次式により求めた。

$$
\eta=\frac{f_{\mathrm{csi}}\left\{T_{\mathrm{w}}+1 / 2\left(T_{R}+T_{c}\right)\right\}}{F_{\mathrm{eal}}\left(T_{\mathrm{R}} \cdot T_{W}+1 / 2 T_{c}\right) / T_{R}}
$$

補正量は $\left(T_{R}, T_{W_{2}}, T_{c}\right)=(10 \mathrm{~s}, 11 \mathrm{~s}, 6 \mathrm{~s})$ の場合加最大 で,約2.5\%であった。このよ5にして得た ${ }^{235} \mathrm{U},{ }^{239} \mathrm{Pu}$, ${ }^{23} \mathrm{U}$ の $\beta$ 線瞬時照射崩㙥熱をそれぞれ Table 5 (a) (c) に示すととるにFig. 6 (a)〜 c)に図示する。瞬時照射崩 壊熱は冷却時間の逆数にほぼ比例するので，令却時間

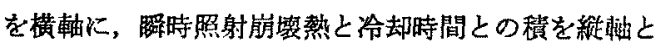
して図示してある。

\section{(3) 讙差評価}

測定誤差の要因として，(1)ハルス波高分布の統計誤 差，(2)パルス波高分扼をエネルギースペクトルに変換 する際に生じる誤差, (3Ti箈による後方散乱補正保数 の䛱差，(4) $\beta-\gamma$ 升別用透過型比例計数管の不感時間の 補正に伴 5誤差, (5)低エネルギー部へ外挿されたスぺ

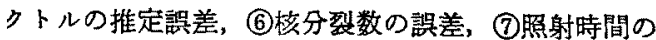
誤差，(8)測定時間の僸差を考虑した。(1), (2), (3)の䛊差 はFERDOR コート内で評価され，その結果が崩壊熱 に与える愦差は1〜2.5\%の範囲である。(4)の款溠は $2.5 \%$ 以下である。(5)推定スベクトルには 10\%の蚂 差を与えているが，その結果が崩壊熱に与える誤差は 
Table $4(a) \sim(c) \quad \beta$-ray energy release and yields from fission products

Table 4/a) ${ }^{235} \mathrm{U}$ created by fast-neutron fission of ${ }^{285} \mathrm{U},{ }^{289} \mathrm{Pu},{ }^{288} \mathrm{U}$

\begin{tabular}{cccccc}
$\begin{array}{c}\text { Waiting } \\
\text { Time } \\
\text { (s) }\end{array}$ & $\begin{array}{c}\text { Counting } \\
\text { Time } \\
\text { (s) }\end{array}$ & $\begin{array}{c}\text { Cooling } \\
\text { Time } \\
\text { (s) }\end{array}$ & $\begin{array}{c}\text { Energy Release } \\
\text { (MeV/fission) }\end{array}$ & $\begin{array}{c}\text { Yield } \\
\text { (betas/fission) }\end{array}$ & $\begin{array}{c}\text { Average Beta } \\
\text { Energy } \\
\text { (MeV/beta) }\end{array}$ \\
\hline (1) Irradiation Time $=10 s$, Number of Fissions $=(1.248 \pm 0.042) \times 10^{7}$ fissions \\
\hline 11 & 6 & 19 & $0.246 \pm 0.012$ & $0.169 \pm 0.010$ & $1.455 \pm 0.062$ \\
25 & 10 & 35 & $0.198 \pm 0.009$ & $0.150 \pm 0.008$ & $1.323 \pm 0.060$ \\
45 & 10 & 55 & $0.115 \pm 0.005$ & $0.0926 \pm 0.0052$ & $1.237 \pm 0.061$ \\
75 & 20 & 90 & $0.130 \pm 0.006$ & $0.108 \pm 0.006$ & $1.201 \pm 0.059$ \\
115 & 40 & 140 & $0.154 \pm 0.007$ & $0.132 \pm 0.007$ & $1.167 \pm 0.056$ \\
195 & 60 & 230 & $0.125 \pm 0.005$ & $0.111 \pm 0.006$ & $1.132 \pm 0.056$ \\
315 & 80 & 360 & $0.103 \pm 0.005$ & $0.0915 \pm 0.0052$ & $1.125 \pm 0.059$ \\
495 & 100 & 550 & $0.0852 \pm 0.0039$ & $0.0743 \pm 0.0042$ & $1.146 \pm 0.061$ \\
795 & 200 & 900 & $0.0974 \pm 0.0043$ & $0.0928 \pm 0.0053$ & $1.049 \pm 0.055$ \\
1395 & 400 & 1600 & $0.109 \pm 0.005$ & $0.106 \pm 0.006$ & $1.030 \pm 0.053$ \\
2195 & 500 & 2450 & $0.0831 \pm 0.0039$ & $0.0811 \pm 0.0047$ & $1.025 \pm 0.057$ \\
3195 & 600 & 3500 & $0.0638 \pm 0.0032$ & $0.0630 \pm 0.0037$ & $1.013 \pm 0.061$ \\
\hline
\end{tabular}

(2) Irradiation Time $=10$ s, Number of Fissions $=(1.474 \pm 0.049) \times 10^{7}$ fissions

$\begin{array}{rrrlll}17 & 8 & 26 & 0.227 \pm 0.010 & 0.168 \pm 0.009 & 1.348 \pm 0.059 \\ 35 & 10 & 45 & 0.147 \pm 0.006 & 0.118 \pm 0.007 & 1.249 \pm 0.060 \\ 55 & 20 & 70 & 0.178 \pm 0.007 & 0.146 \pm 0.008 & 1.224 \pm 0.056 \\ 95 & 20 & 110 & 0.103 \pm 0.004 & 0.0872 \pm 0.0047 & 1.186 \pm 0.057 \\ 155 & 40 & 180 & 0.113 \pm 0.005 & 0.0963 \pm 0.0052 & 1.173 \pm 0.056 \\ 255 & 60 & 290 & 0.0931 \pm 0.0040 & 0.0810 \pm 0.0044 & 1.149 \pm 0.057 \\ 395 & 100 & 450 & 0.0974 \pm 0.0042 & 0.0874 \pm 0.0049 & 1.115 \pm 0.057 \\ 595 & 200 & 700 & 0.127 \pm 0.005 & 0.117 \pm 0.007 & 1.086 \pm 0.056 \\ 995 & 400 & 1200 & 0.148 \pm 0.006 & 0.141 \pm 0.008 & 1.047 \pm 0.053 \\ 1795 & 400 & 2000 & 0.0847 \pm 0.0038 & 0.0824 \pm 0.0047 & 1.029 \pm 0.057 \\ 2695 & 500 & 2950 & 0.0663 \pm 0.0032 & 0.0638 \pm 0.0036 & 1.040 \pm 0.059 \\ 3795 & 600 & 4100 & 0.0543 \pm 0.0030 & 0.0518 \pm 0.0030 & 1.048 \pm 0.069\end{array}$

(3) Irradiation Time $=60 \mathrm{~s}$, Number of Fissions $=(8.724 \pm 0.222) \times 10^{7}$ fissions

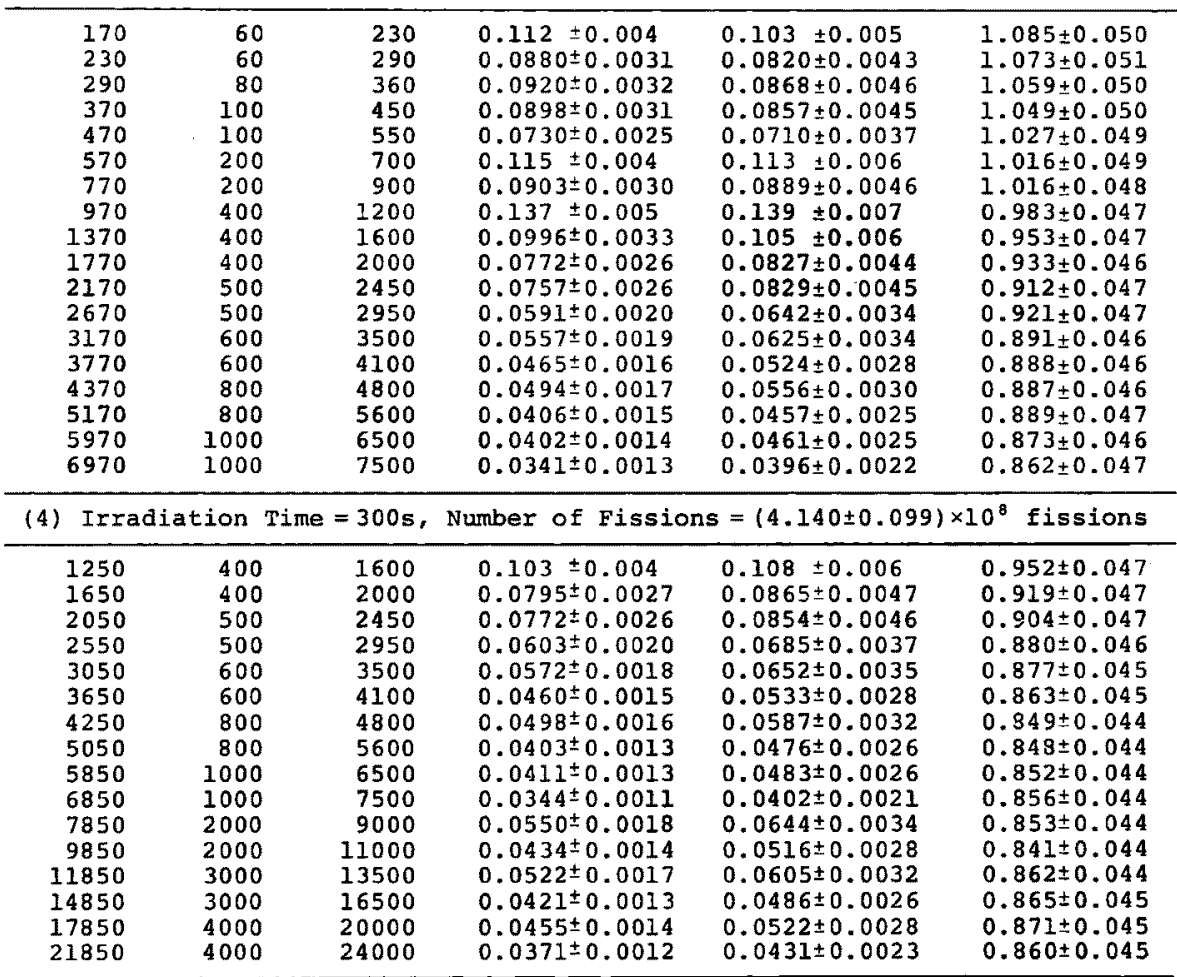

a: $T_{\text {eool }}=T_{\text {wats }}+0.5 \times\left(T_{\text {irred }}+T_{\text {eount }}\right)$ 
Table 4(b) ${ }^{230} \mathrm{Pu}$

\begin{tabular}{cccccc}
$\begin{array}{c}\text { Waiting } \\
\text { Time } \\
\text { (s) }\end{array}$ & $\begin{array}{c}\text { Counting } \\
\text { Time } \\
\text { (s) }\end{array}$ & $\begin{array}{c}\text { Cooling } \\
\text { Time } \\
(\mathbf{s})\end{array}$ & $\begin{array}{c}\text { Energy Release } \\
\text { (Mev/fission) }\end{array}$ & $\begin{array}{c}\text { Yield } \\
\text { (betas/fission) }\end{array}$ & $\begin{array}{c}\text { Average Beta } \\
\text { Energy } \\
\text { (Mev/beta) }\end{array}$ \\
\hline (1) Irradiation Time $=10$, number of Fissions $=(1.620 \pm 0.057) \times 10^{7}$ fissions \\
\hline 11 & 6 & 19 & $0.183 \pm 0.009$ & $0.130 \pm 0.008$ & $1.408 \pm 0.060$ \\
25 & 10 & 35 & $0.161 \pm 0.007$ & $0.125 \pm 0.007$ & $1.283 \pm 0.058$ \\
45 & 10 & 55 & $0.0989 \pm 0.0046$ & $0.0795 \pm 0.0045$ & $1.244 \pm 0.059$ \\
75 & 20 & 90 & $0.113 \pm 0.005$ & $0.0946 \pm 0.0052$ & $1.193 \pm 0.054$ \\
115 & 40 & 140 & $0.136 \pm 0.006$ & $0.117 \pm 0.006$ & $1.163 \pm 0.053$ \\
195 & 60 & 230 & $0.111 \pm 0.005$ & $0.0967 \pm 0.0053$ & $1.146 \pm 0.053$ \\
315 & 80 & 360 & $0.0940 \pm 0.0042$ & $0.0831 \pm 0.0047$ & $1.131 \pm 0.055$ \\
495 & 100 & 550 & $0.0749 \pm 0.0036$ & $0.0677 \pm 0.0040$ & $1.106 \pm 0.060$ \\
795 & 200 & 900 & $0.0911 \pm 0.0041$ & $0.0833 \pm 0.0047$ & $1.094 \pm 0.055$ \\
1395 & 400 & 1600 & $0.0996 \pm 0.0045$ & $0.0938 \pm 0.0054$ & $1.062 \pm 0.054$ \\
2195 & 500 & 2450 & $0.0762 \pm 0.0036$ & $0.0755 \pm 0.0045$ & $1.009 \pm 0.057$ \\
3195 & 600 & 3500 & $0.0553 \pm 0.0028$ & $0.0551 \pm 0.0032$ & $1.003 \pm 0.060$ \\
\hline
\end{tabular}

(2) Irradiation Time $=10 \mathrm{~s}$, Number of Fissions $=(1.719 \pm 0.058) \times 10^{7}$ fissions

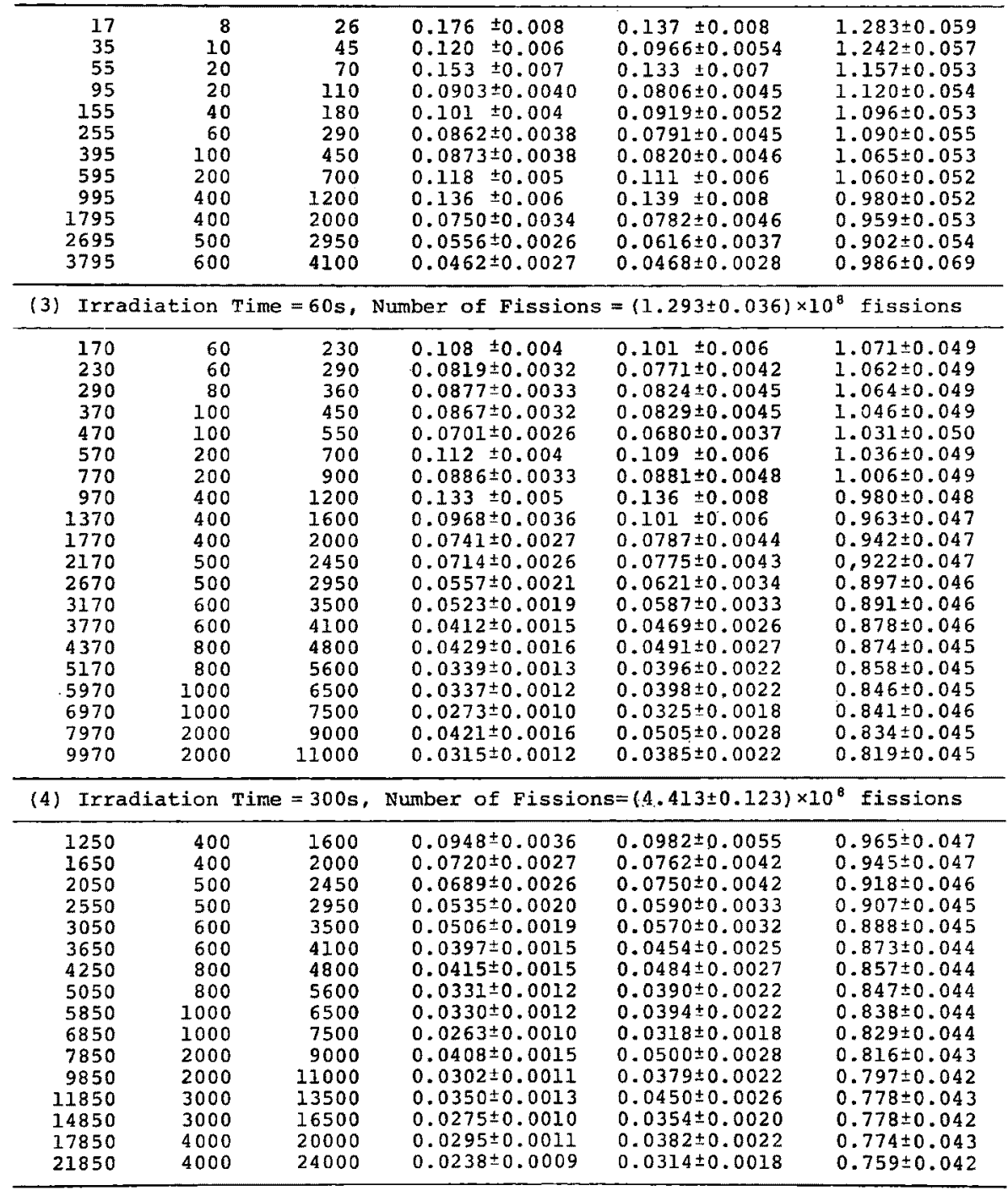

$a: \quad T_{\text {cool }}=T_{\text {malt }}+0.5 \times\left(T_{\text {Irrad }}+T_{\text {count }}\right)$ 
Table 4(c) ${ }^{28 s} \mathrm{U}$

\begin{tabular}{|c|c|c|c|c|c|}
\hline $\begin{array}{l}\text { Waiting } \\
\text { Time } \\
\text { (s) }\end{array}$ & $\begin{array}{l}\text { Counting } \\
\text { Time } \\
\text { (s) } \\
\end{array}$ & $\begin{array}{l}\text { Cooling } \\
\text { Time } \\
\text { (s) }\end{array}$ & $\begin{array}{c}\text { Energy Release } \\
(\mathrm{MeV} / \mathrm{fission})\end{array}$ & $\begin{array}{l}\text { Yield } \\
\text { (betas/fission) }\end{array}$ & $\begin{array}{l}\text { Average Beta } \\
\text { Energy } \\
\text { (Mev/beta) } \\
\end{array}$ \\
\hline \multicolumn{6}{|c|}{ (1) Irradiation Time $=10 \mathrm{~s}$, } \\
\hline 11 & 6 & 19 & $0.173 \pm 0.010$ & $0.127 \pm 0.009$ & $1.368 \pm 0.059$ \\
\hline 25 & 10 & 35 & $0.143 \pm 0.007$ & $0.116 \pm 0.007$ & $1.236 \pm 0.056$ \\
\hline $4 \dot{5}$ & 10 & 55 & $0.0923 \pm 0.0044$ & $0.0778 \pm 0.0046$ & $1.186 \pm 0.055$ \\
\hline 75 & 20 & 90 & $0.105 \pm 0.005$ & $0.0888 \pm 0.0052$ & $1.177 \pm 0.054$ \\
\hline $1 \div 5$ & 40 & 140 & $0.129 \pm 0.006$ & $0.113 \pm 0.007$ & $1.140 \pm 0.053$ \\
\hline 195 & 60 & 230 & $0.109 \pm 0.005$ & $0.0994 \pm 0.0058$ & $1.100 \pm 0.053$ \\
\hline 315 & 80 & 360 & $0.0883 \pm 0.0039$ & $0.0818 \pm 0.0048$ & $1.080 \pm 0.054$ \\
\hline$\therefore 95$ & 100 & 550 & $0.0717 \pm 0.0032$ & $0.0682 \pm 0.0040$ & $1.051 \pm 0.053$ \\
\hline Tミ5 & 200 & 900 & $0.0894 \pm 0.0039$ & $0.0871 \pm 0.0051$ & $1.027 \pm 0.051$ \\
\hline $13 \equiv 5$ & 400 & 1600 & $0.0995 \pm 0.0045$ & $0.102 \pm 0.006$ & $0.973 \pm 0.052$ \\
\hline$\because \Xi \overline{5}$ & 500 & 2450 & $0.0735 \pm 0.0033$ & $0.0789 \pm 0.0048$ & $0.932 \pm 0.050$ \\
\hline $3: 55$ & 600 & 3500 & $0.0566 \pm 0.0027$ & $0.0634 \pm 0.0039$ & $0.892 \pm 0.051$ \\
\hline \multicolumn{6}{|c|}{ (引) $̇ こ=\equiv \Xi i \equiv t i o n$ Time $=10 \mathrm{~s}$, Number of Fissions $=(3.432 \pm 0.121) \times 10^{7}$ fissions } \\
\hline 17 & 8 & 26 & $0.172 \pm 0.009$ & $0.132 \pm 0.009$ & $1.305 \pm 0.057$ \\
\hline 35 & 10 & 45 & $0.117 \pm 0.006$ & $0.0955 \pm 0.0056$ & $1.229 \pm 0.055$ \\
\hline 55 & 20 & 70 & $0.148 \pm 0.007$ & $0.123 \pm 0.007$ & $1.204 \pm 0.053$ \\
\hline 95 & 20 & 110 & $0.0868 \pm 0.0038$ & $0.0725 \pm 0.0040$ & $1.197 \pm 0.054$ \\
\hline 153 & 40 & 180 & $0.0937 \pm 0.0040$ & $0.0831 \pm 0.0047$ & $1.128 \pm 0.053$ \\
\hline 255 & 60 & 290 & $0.0815 \pm 0.0035$ & $0.0734 \pm 0.0041$ & $1.110 \pm 0.053$ \\
\hline 395 & 100 & 450 & $0.0865 \pm 0.0036$ & $0.0805 \pm 0.0046$ & $1.076 \pm 0.053$ \\
\hline 595 & 200 & 700 & $0.114 \pm 0.005$ & $0.109 \pm 0.006$ & $1.042 \pm 0.051$ \\
\hline 995 & 400 & 1200 & $0.134 \pm 0.006$ & $0.134 \pm 0.008$ & $0.999 \pm 0.051$ \\
\hline 1795 & 400 & 2000 & $0.0733 \pm 0.0031$ & $0.0769 \pm 0.0045$ & $0.953 \pm 0.050$ \\
\hline 2695 & 500 & 2950 & $0.0582 \pm 0.0026$ & $0.0611 \pm 0.0036$ & $0.952 \pm 0.052$ \\
\hline 3795 & 600 & 4100 & $0.0425 \pm 0.0020$ & $0.0493 \pm 0.0030$ & $0.863 \pm 0.051$ \\
\hline \multicolumn{3}{|c|}{ (3) Irradiation Time $=100 \mathrm{~s}$, } & Number of $F$ & $s=(3.072 \pm 0.078)$ & $10^{8}$ fissions \\
\hline 150 & 60 & 230 & $0.119 \pm 0.006$ & $0.105 \pm 0.0$ & $1.131 \pm 0.051$ \\
\hline 210 & 60 & 290 & $0.0893 \pm 0.0038$ & $0.0804 \pm 0.0047$ & $1.111 \pm 0.051$ \\
\hline 270 & 80 & 360 & $0.0928 \pm 0.0037$ & $0.0848 \pm 0.0048$ & $1.094 \pm 0.050$ \\
\hline 350 & 100 & 450 & $0.0914 \pm 0.0035$ & $0.0852 \pm 0.0047$ & $1.073 \pm 0.050$ \\
\hline 450 & 100 & 550 & $0.0735 \pm 0.0027$ & $0.0696 \pm 0.0038$ & $1.056 \pm 0.050$ \\
\hline 550 & 200 & 700 & $0.115 \pm 0.004$ & $0.110 \pm 0.006$ & $1.048 \pm 0.049$ \\
\hline 750 & 200 & 900 & $0.0884 \pm 0.0031$ & $0.0850 \pm 0.0045$ & $1.039 \pm 0.049$ \\
\hline 950 & 400 & 1200 & $0.131 \pm 0.005$ & $0.129 \pm 0.007$ & $1.015 \pm 0.048$ \\
\hline 1350 & 400 & 1600 & $0.0964 \pm 0.0033$ & $0.0367 \pm 0.0051$ & $0.997 \pm 0: 048$ \\
\hline 1750 & 400 & 2000 & $0.0745 \pm 0.0025$ & $0.0747 \pm 0.0039$ & $0.997 \pm 0.047$ \\
\hline 2150 & 500 & 2450 & $0.0725 \pm 0.0024$ & $0.0739 \pm 0.0038$ & $0.981 \pm 0.046$ \\
\hline 2650 & 500 & 2950 & $0.0573 \pm 0.0019$ & $0.0589 \pm 0.0031$ & $0.973 \pm 0.046$ \\
\hline 3150 & 600 & 3500 & $0.0546 \pm 0.0018$ & $0.0568 \pm 0.0030$ & $0.961 \pm 0.046$ \\
\hline 3750 & 600 & 4100 & $0.0442 \pm 0.0015$ & $0.0465 \pm 0.0024$ & $0.951 \pm 0.046$ \\
\hline 4350 & 800 & 4800 & $0.0475 \pm 0.0016$ & $0.0502 \pm 0.0026$ & $0.947 \pm 0.046$ \\
\hline 5150 & 800 & 5600 & $0.0392 \pm 0.0013$ & $0.0417 \pm 0.0022$ & $0.939 \pm 0.046$ \\
\hline 5950 & 1000 & 6500 & $0.0395 \pm 0.0013$ & $0.0429 \pm 0.0023$ & $0.919 \pm 0.046$ \\
\hline 6950 & 1000 & 7500 & $0.0333 \pm 0.0011$ & $0.0353 \pm 0.0018$ & $0.943 \pm 0.046$ \\
\hline 7950 & 2000 & 9000 & $0.0542 \pm 0.0018$ & $0.0576 \div 0.0030$ & $0.940 \pm 0.046$ \\
\hline 9950 & 2000 & 11000 & $0.0424 \pm 0.0014$ & $0.0457 \pm 0.0024$ & $0.927 \pm 0.046$ \\
\hline 11950 & 3000 & 13500 & $0.0519 \pm 0.0018$ & $0.0564 \pm 0.0030$ & $0.920 \pm 0.046$ \\
\hline 14950 & 3000 & 16500 & $0.0421 \pm 0.0014$ & $0.0458 \pm 0.0024$ & $0.921 \pm 0.046$ \\
\hline 17950 & 4000 & 20000 & $0.0455 \pm 0.0015$ & $0.0488 \pm 0.0025$ & $0.933 \pm 0.045$ \\
\hline 21950 & 4000 & 24000 & $0.0380 \pm 0.0013$ & $0.0416 \pm 0.0022$ & $0.913 \pm 0.046$ \\
\hline
\end{tabular}

$a: \quad T_{\text {cool }}=T_{\text {molt }}+0.5 \times\left(T_{\text {irrad }}+T_{\text {coudt }}\right)$ 


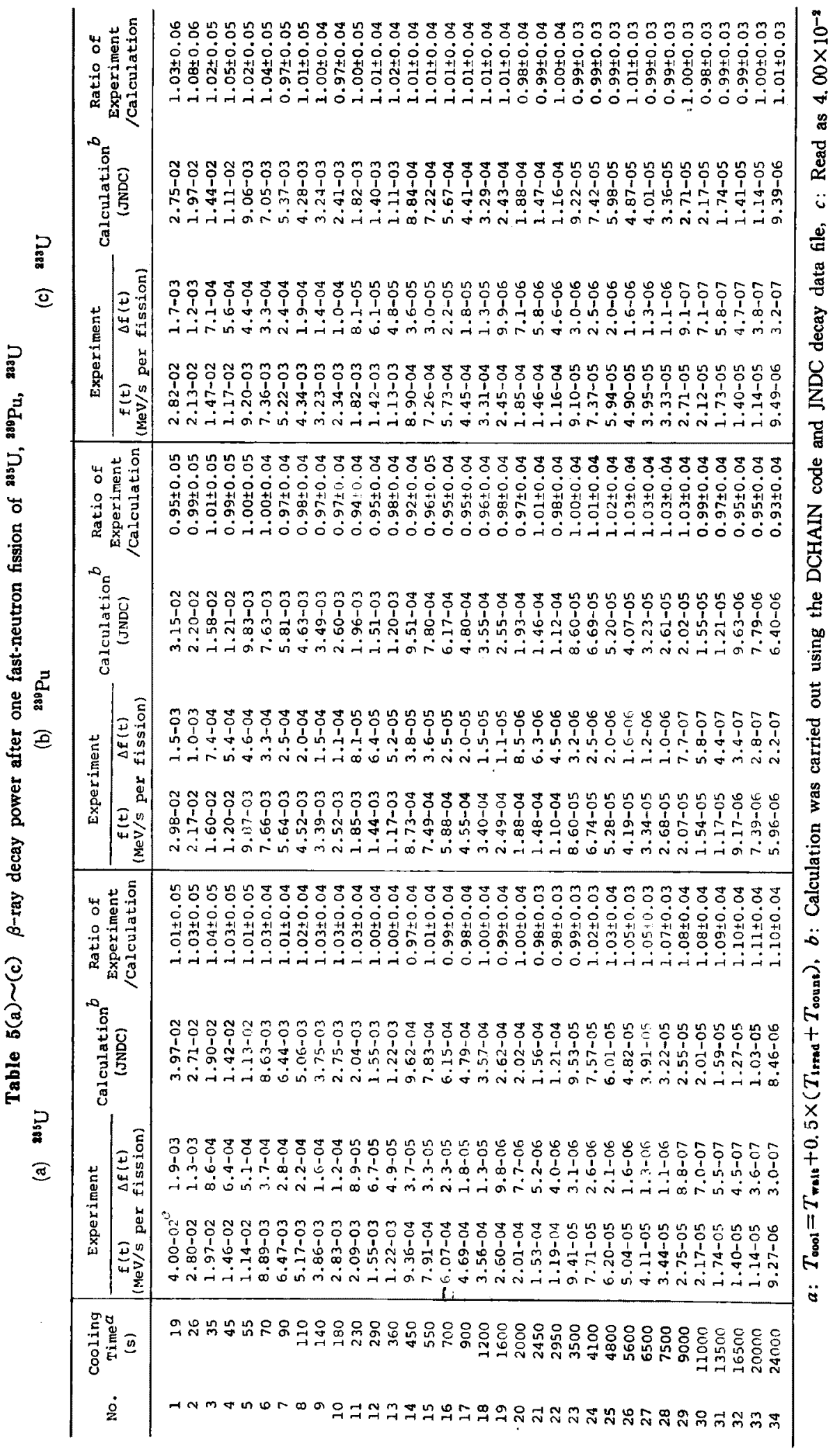

( 71$)$ 


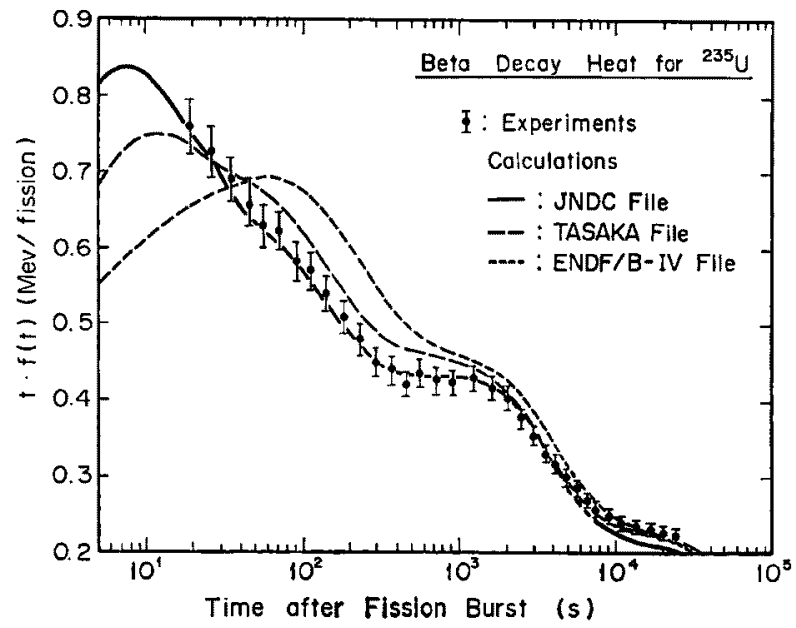

(a) ${ }^{285} \mathrm{U}$

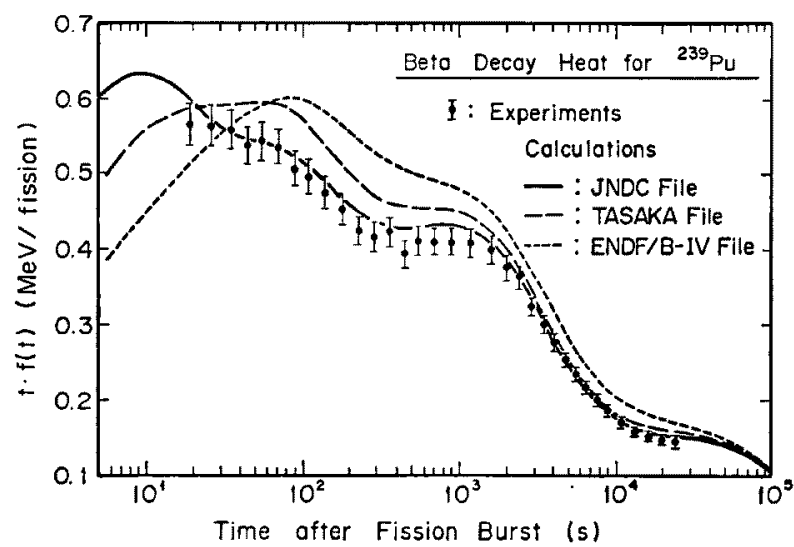

(b) ${ }^{289} \mathrm{Pu}$

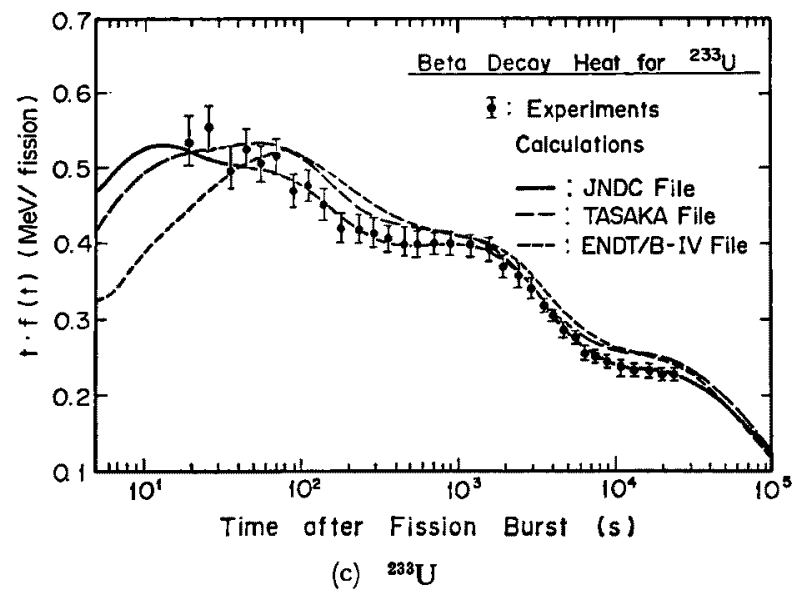

Comparison of the experimental results with three summation calculations using the DCHAIN code.

Fig. 6(a) (c) $\beta$ energy emission tate following an instantaneous pulse of fast-neutron fissions of ${ }^{285} \mathrm{U},{ }^{239} \mathrm{Pu}$ and ${ }^{233} \mathrm{U}$
約 $1 \%$ であ。(6)核分裂数の誤差は測定上 の誤差と使用した核データの誤差との和であ り，2.5〜4\%の篹囲である。一方，照射時間 の誤差は $0.1 \mathrm{~s}$ ，測定時間の埕差は $1 \%$ と推 定した。

上記の各誤差要因から生じる実験誤差はす ぺて独立と考光，各鿁差の 2 乗和の平方根と して全実験誤差を得た。この結果，全実験虽 羑は 1 標準作差(10)の值で5\%以内であっ だ。

\section{IV. 䌊和計算值および他の 実験値之の比較}

\section{1. 総和計算との比較}

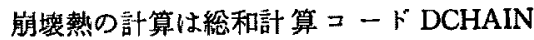
(18)を使用し，現在国内でよく使用されている JNDC FP 崩培データライブラリー(19) ( (21), TASAKA FP 崩䁁データライブラリー(22) おょび ENDF/B-IV FP 崩壊データライブ ラリー (23)の3 種の独立なライブラリーを用 いて行なった。崩坮熱の計算において，生成 された FP の中性子反応の効果が無視できる 条件の場合，核分裂を起こす中性子のエネル ギースベクトルの效果は核分裂取率の中性子 エネルギー依存性として取り扱われる。しか し，熱中性子と核分裂中性子エネルギースペ クトルに対する核分裂収率を用いた総和計算 值の間には大きな差はないか。方，試料を 照射した場の中性子エネルギースペクトルは Fig. 1 に示したよらに核分裂中性子エネルギ ースペクトル上り若干軟かい特性をむってい る。したがって， ${ }^{205} \mathrm{U}$ と ${ }^{280} \mathrm{Pu}$ についての計 算では核分裂中性子ェネルギースペクトルに 対する核分裂收率を用い， ${ }^{238}$ Uについては用 いた FP 崩壊データライブラリーには核分裂 中性子ェネルギースペクトルに対する核分裂 収率が内蔵されていないので，熱中性子ェネ ルギースペクトルに対する核分列収率を用い た。

${ }^{235} \mathrm{U},{ }^{230} \mathrm{Pu},{ }^{288} \mathrm{U}$ について，それぞれ3つの 総和計算值は実験値とともにFig. $6(\mathrm{a}) \sim(\mathrm{c})$ に 図示してある。 ${ }^{235} \mathrm{U},{ }^{230} \mathrm{Pu},{ }^{238} \mathrm{U}$ のいずれの場 合も3つの計算值間で食い違いがあり，特に 短い椧却時間に括いて食い違いが大きい。 た, JNDC FP 崩壤データライブラリーを用 
いた総和計算値が全令却時間領域に わたって央験値を非常によく再現して いる。このことはTable $5(\mathrm{a}) \sim(\mathrm{c})$ K載 せてある实験值と JNDC FP崩壤デー タライブラリーを用いた総和計算值と の此較において, ${ }^{235} \mathrm{U}$ に扰いて 7,500 $\mathrm{s}$ 以上の冷却時間範囲で総和計算値が 若干過小評価する傾向があることを除 けば，実鈳誤差の範囲て総和計算值と 実験値とが一致していることからもわ かる。

\section{2. 他の実験値との比較}

第 I 章で述べたMurphyらによる10 s 間一定核分裂反応率て照射した後， 数 $10 \mathrm{~s} \sim 10^{7} \mathrm{~s}$ の冷却時間に括いて測 定された $\beta$ 線崩壊熱の実験値と今回の 実験値とを比較するため，今回の実験 值を $10^{5} \mathrm{~s}$ 照射した場合の有限時問照 射崩㙘熱の值に以下に述へる方法で変 換した。一定核分裂反応率での照射 でFP の中性子反応が無視できる場 合, $T_{R}$ 時間照射後 $T_{W} か ら\left(T_{W}+T_{C}\right)$ までの時間内に FP から放出されるエ ネルギーと, $T_{c}$ 時間照射後 $T_{W} か ら C\left(T_{W}\right.$ $\left.+T_{B}\right)$ までの時間内に FP から放出さ れるェネルギーとは等しい。つまり

$$
\begin{aligned}
& T_{R} \cdot E\left(T_{R}, T_{W}+1 / 2 T_{C}\right) \\
& =T_{C} \cdot E\left(T_{C}, T_{W}+1 / 2 T_{R}\right)
\end{aligned}
$$

が成り立つ。したがって，(7)と(12) 式の関保から, Table 4 (a) (c)k示し たエネルギー放出量は測定時間の楖に 示した時間 $T_{c}$ を照射時間とし，待ち時 間の㯗に示した時問 $T_{\mathbf{W}}$ と照射時間の 椚に示した時間 $T_{R}$ を用いた $\left(T_{W}+1 / 2\right.$ $T_{R}$ )を冷却時間とする有限時間照射崩 壊熱とみなすことができる。一方，照 射時間 $\left(t_{3}-t_{1}\right)$, 冷却時間 $t_{1}$ の有限時 間照射崩壊熱 $F\left(t_{3}-t_{1}, t_{1}\right)$ \&瞬時照射 崩壤熱 $f(t)$ を用いて次のよ5に表わさ れる。

$$
F\left(t_{3}-t_{1}, t_{1}\right)=\int_{t_{1}}^{t_{1}} f(t) d t
$$

ここで, $t_{1}<t_{2}<t_{3}$ の関係にある時刻 $t_{2}$ を用いて

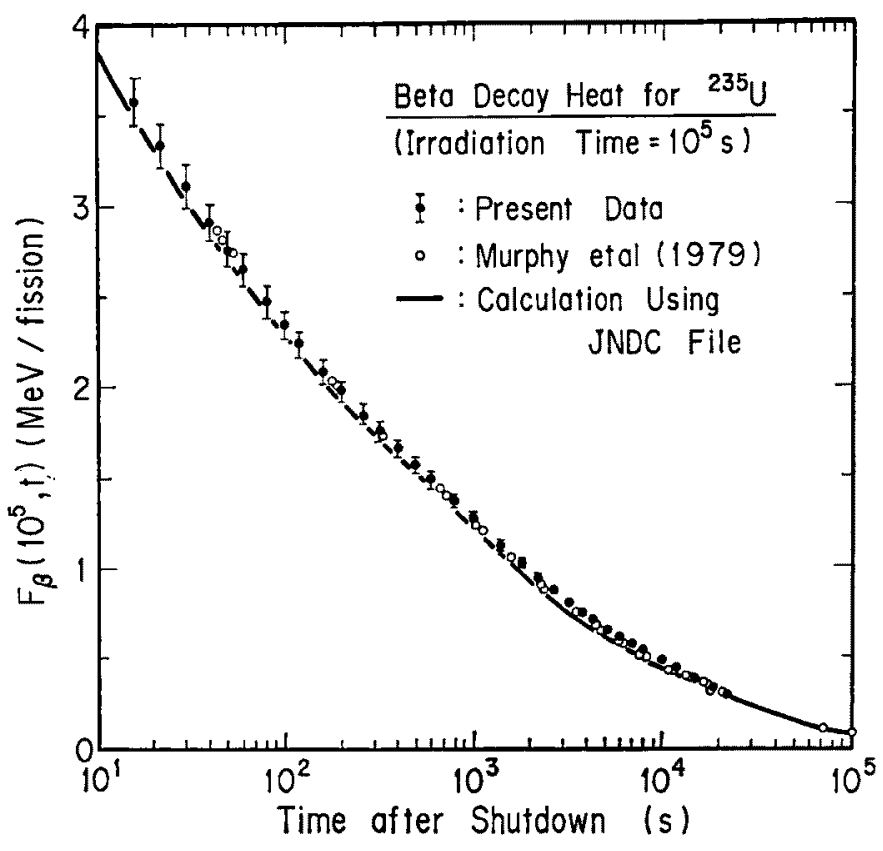

(a) ${ }^{235} \mathrm{U}$

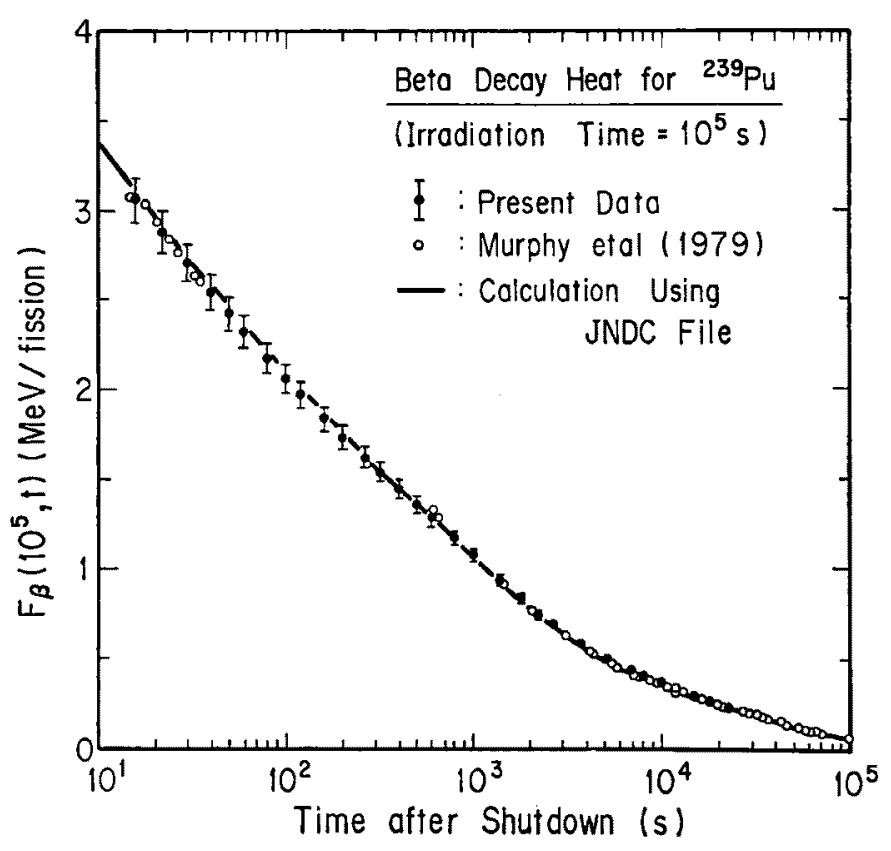

(b) ${ }^{230} \mathrm{Pu}$

Comparison of the present results with other experimental results and the summation calculation using JNDC FP decay data library.

Fig. 7 (a), (b) $\beta$ energy emission rate for $10^{5} \mathrm{~s}$ irradiation of ${ }^{285} \mathrm{U}$ and ${ }^{239} \mathrm{Pu}$ at constant fission rate without neutron capture in fission products 


$$
\begin{aligned}
F\left(t_{3}-t_{1}, t_{1}\right)= & F\left(t_{2}-t_{1}, t_{1}\right)+F\left(t_{8}-t_{2}, t_{2}\right) \\
& =\int_{t_{1}}^{t_{3}} f(t) d t+\int_{t_{1}}^{t_{2}} f(t) d t
\end{aligned}
$$

となる。したがって, 照射時間 $t_{3}-t_{1}=10^{3} \mathrm{~s}$ とし, $t_{1}$ $=22,000 \mathrm{~s}, t_{2}=26,000 \mathrm{~s}$ とすると，(14)式の值は

$$
F\left(10^{5}, 22,000\right)=\int_{22,000}^{28,000} f(t) d t+\int_{26,000}^{128,000} f(t) d t
$$

となる。(14')式の在辺第 1 項は Table 4(a) (c) K示 したェネルギー放出量の最下段の值に相当する。第 2 項は今回の契験值からは得られない値であり，NDC FP 崩壊データライブラリーを用いた総和計算から求 めた。 $F\left(10^{5}, 18,000\right)$ の值は $t_{1}=18,000 \mathrm{~s}, t_{2}=22,000$ s として, Table 4 (a) (c)の下より2段目の值と $F$ $\left(10^{5}, 22,000\right)$ の值との和として与古られる。この手順 を繰り返すことにより，今回の奏験值を $10^{5} \mathrm{~s}$ 照射に 対する冷却時間 $11 \sim 26,000 \mathrm{~s}$ の範困での有限時間照 射崩䤤熱に变換した。

${ }^{285} \mathrm{U}$ と ${ }^{280} \mathrm{Pu}$ について，今回の奏験值を $10^{5} \mathrm{~s}$ 照射

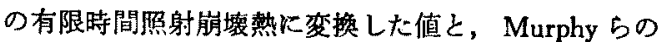
害䮖值および JNDC FP 崩垻データライブラリーを用 いた総和計算值とを比皎した図を Fig.7 (a), (b)に示 す。Murphy らの史験值の誴差は約 $5 \%$ \%す。 ${ }^{235} U$, ${ }^{238} \mathrm{Pu}$ とるに2つの実験值は非常によく一致している。 一万，総和計算值との比較では， ${ }^{295} U$ の場合は総和計 算值が若干過小評価する傾向にあるが実験誤差の範围 で一致して㧍り、 ${ }^{2 a} \mathrm{Pu}$ の場合は総和計算値は実験値 とよく一致している。

\section{V. 結 論}

${ }^{235} \mathrm{U},{ }^{268} \mathrm{Pu},{ }^{233} \mathrm{U}$ の高速中性子核分裂による FP から の $\beta$ 線崩壊熱を冷却時間 $19 \sim 24,000 \mathrm{~s}$ の範囲に拈ける 瞬時照射境崩熱の形で得た。それらの荚験誤差(10)は 5\%以内であった。JNDC, TASAKA, ENDF/B-IVの 3 種の FP 崩壊データライブラリーを用いた総和計算 値と比較検討の結果，JNDC FP 崩堎データライブラ リーを用いた総和計算值が， ${ }^{285} \mathrm{U}$ の場合 7,500 $\mathrm{s}$ 以上 の冷却時間範睭における若干過小評価の傾向にあるこ とを除けば,非常によく今回の実駼值を再現することが わかった。また，今回の実験值は照射時間の異なる他 の㬰験值とる非常によく一致することが確認された。

今回の実験值は高速中性子核分裂による FP からの $\beta$ 線崩壊熱を橓時照射条件に近い照射時間で照射した

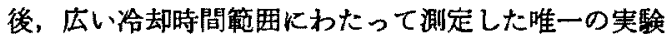
值であり，先に報告した $\gamma$ 線崩塄熱の実験値と合わせ て，高速增殖炉の安全性評価上必要とされる精度を充

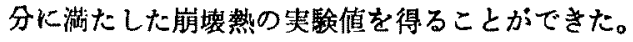

本研究の一部は動力炬・核然料開発 事業団からの受 記研究として行われた。大谷惕夫氏初めご関係の方々 に感謝いたします。東京大学原子核研究所の川上宏 金, 藤田雄三，中村间司，小佐古敏萑の各氏には空芯 $\beta$ 線スペクトロメータを用いた実験に特けるご協力を， 日本原子力斫究所の田圾完二,井原 均の両氏には総和 計算コードの使用に批けるご協力を，東京大学工学部 原子力工学研究施設の岡 芳明, 中沢正治, 橋倉宏行, 此 村守,柳沢一郎(現，三菱原子力工業(侏)の各氏および 同研究施設原子炉本部の方々には賈重なご助言,ご協 力を頂きました。ここに感暗の意を表します。

\section{一一弆考文献—}

(1) Fisher, P.C., ENGLe, L.B.: Phys. Rev., 134, B796 (1964).

(2) Bunney, L.R., SAM, D.: Nucl. Sci. Eng., 29, 432 (1967).

(3) MURPHY, M.F., et al.: Experiments to determine the rate of beta energy release following fission of ${ }^{239} \mathrm{Pu}$ and ${ }^{285} \mathrm{U}$ in fast reactor, $A E E W-R 1212$, (1979).

(4) Johnston, K.: J. Nucl. Energy, 19, 527 (1965).

(5) CostA, L., et al.: ibid., 26, 431 (1972).

(6) Devillers, C.: Proc. Second Advisory Group Meeting on Fission Product Nuclear Data, Petten, 1977, IAEA-213.

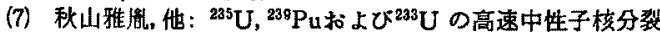
Kよる核分致生成物からの 7 線崩溒熱の测定，原子力誌， 24[9], 709 (1982).

(8) AN, S., et al.: Proc. Int. Symp. Physics of Fast Reactors, Tokyo, 1973.

(9) AN, S., OKA, Y., SAITO, I.: Present status and future program of YAYOI as a fast pulse reactor, UTNL$R$ 0061, (1978).

(10) 中沢正治, 関口 晃:「弥生」線量測定データ集 (1), UTNL $-R$ 0037, (1976).

(ii) OKRENT, D.: Power Reactor Technol., 7, 107(1964).

(12) 久武和夫: 原子核咞究，13，21 (1968).

(13) 藤同 学,久武和夫: INS TL-89，(1966).

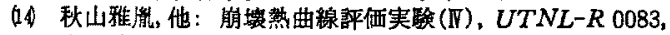
(1980).

(15) RIDER, B.F., MEEK, M.E.: Compilation of fission product yields, NEDO-12154-2 (D), (1977).

(16) LEDERER, C.M., et al.: "Table of Isotopes", (7th ed.), (1978), John Wiley \& Sons.

(17) KENDRICK, H., et al.: An introduction to the principles and use of the FERDOR unfolding code, $G A-9882$, (1970).

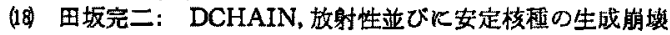
解析コード, JAERI 1250，(1977).

(18) Yamamoto, T., et al.: JNDC FP decay data file, JAERI-M 9357, (1981).

(20) Yoshida, T., NAKasIma, R.: J. Nucl. Sci. Technol., 18[6], 393 (1981).

(1) IHARA, H., et al.: JNDC FP decay and yield data, $J A E R I-M$ 9715, (1981).

(2) TASAKA, K.: Nuclear data library of fission products for decay power calculation, NUREG/CR-0705, TREE-1325, (1979).

(23) ENGLAND, T.R., SCHENTER, R.E. : ENDF/B-NI fissionproduct files; Summary of major nuclide data, $L A$ 6116-MS, (1975). 